Original article

\title{
Micronucleus, alkaline, and human 8-oxoguanine glycosylase 1 modified comet assays evaluation of glass-ionomer cements - in vitro
}

\author{
Elizabeta Galić ${ }^{1}$, Antonija Tadin ${ }^{2}$, Nada Galić3 ${ }^{3}$ Vilena Kašuba ${ }^{4}$, Marin Mladinićc ${ }^{4}$, Ružica Rozgaj ${ }^{4}$, \\ Dolores Biočina-Lukenda ${ }^{2}$, Ivan Galić ${ }^{2}$, and Davor Želježićc \\ Health Center of Split-Dalmatia County ${ }^{l}$, Study of Dental Medicine, School of Medicine, University of Split ${ }^{2}$, Split, \\ Department of Endodontics and Restorative Dental Medicine, School of Dental Medicine, University of Zagreb, \\ Mutagenesis Unit, Institute for Medical Research and Occupational Health", Zagreb, Croatia
}

Received in April 2013

CrossChecked in May 2013

Accepted in April 2014

\begin{abstract}
The purpose of this study was to evaluate the genotoxic potential of components leached from two conventional self-curing glass-ionomer cements (Fuji IX and Ketac Molar), and light-curing, resin modified glass-ionomer cements (Vitrebond, Fuji II LC). Evaluation was performed on human lymphocytes using alkaline and hOGG1 modified comet, and micronucleus assays. Each material, polymerised and unpolymerised, was eluted in extracellular saline $\left(1 \mathrm{~cm}^{2} \mathrm{~mL}^{-1}\right)$ for $1 \mathrm{~h}, 1$ day, and 5 days. Cultures were treated with eluates using final dilutions of $10^{-2}, 10^{-3}$, and $10^{-4}$. Alkaline comet assay did not detect changes in DNA migration of treated cells regardless of the ionomer tested, polymerisation state, and elution duration. Glass ionomers failed to significantly influence micronucleus frequency. No oxidative DNA damage in treated lymphocytes was observed using hOGG1 modified comet assay. Obtained results indicate high biocompatibility of all tested materials used in the study under experimental conditions.
\end{abstract}

KEY WORDS: biocompatibility; cytotoxicity; DNA damage; genotoxicity; lymphocytes

The most important requirement for a material to be used in medical applications is its biocompatibility. Dental materials can lead to cell damage of the pulp, gingiva, and oral mucosa. Various tests have been applied to assess the risk of such damage (1-4).

Due to their properties, glass ionomer cements (GICs) are widely used as restorative materials in dentistry. Since their commercial introduction, GICs have been available in essentially two types: 'conventional' glass ionomers (CGICs) and resinmodified glass ionomer cements (RMGICs) (5). CGICs are composed of fine calcium fluoroaluminosilicate glass powder and aqueous solutions of polyacrylic acid and its copolymers. RMGICs are usually formulated from fluoro- aluminosilicate glasses, photo-initiators, polyacrylic acid, water, and a water-soluble methacrylate monomer, such as hydroxyethyl methacrylate (HEMA) $(6,7)$.

Despite the improved mechanical properties of RMGICs their biocompatibility is still controversial $(4,5)$. Most of the studies suggested that CGICs revealed minimal toxicity in vitro or in vivo, whereas RMGICs showed significant cytotoxicity and genotoxicity $(8,10-12)$. There are sufficient data demonstrating that the liberated substances may diffuse pulp ward in high quantities (triethyleneglycoldimethacrylate - TEGDMA, HEMA), particularly through thin dentin layers or after acid-etching of dentin. It appears that high quantities of these 
components may result in pulpal inflammation (13). De Souza Costa et al. (10) reported that Vitrebond reduced viability of odontoblasts by $74.6 \%$, Fuji II LC by $45.5 \%$, Fuji IX by $29.5 \%$, and Ketac Molar by $32.5 \%$. However, Koulaouzidou et al. (14) found that Fuji II LC showed only minimal cytotoxicity and mild antiproliferative effect on three cell lines (L929, BHK21/C13, and RCP-C2A). Do Nascimento et al. (15) reported that Vitrebond could cause marked inflammatory pulpal reactions and a large necrotic zone. Six et al. (16) used Fuji IX on rats' upper molars and found that after 8 days it caused disruption of the odontoblastic layer, blood vessels' dilatation, and inflammatory reaction of the pulp with presence of bacteria in dentinal tubules. However, after 30 days, pulpal tissue was again healthy and looked normal (16).

Thus, the aim of this in vitro study was to comparatively evaluate possible genotoxicity of monomers released from two types of commercially available groups of glass ionomers, CGICs and RMGICs, with respect to their polymerisation state and time elapsed from the setting of the materials. To detect possible differences in their mechanism of actions two different cytogenetic techniques were applied on human lymphocyte cultures: comet and micronucleus assay. In addition, human 8-oxoguanine glycosylase 1 (hOGG1) enzyme modified comet assay was performed to evaluate possible oxidative DNA damage.

\section{MATERIALS AND METHODS}

\section{Blood sampling}

Each material was tested on lymphocytes of three young, healthy, non-smoking voluntary donors. The donors were one male and two females with mean age $29.33 \pm 1.69$. According to a questionnaire filled by donors, in 12 months prior to blood sampling, they had not been exposed to any physical or chemical agents that might have interfered with the results of genotoxicity testing. Blood was drawn by antecubital venipuncture into heparinised vacutainers (Becton Dickenson, Plymouth, UK). All donors were acquainted with the study and they willingly signed permissions to use their blood samples for scientific purposes. All described procedures were in accordance with the high ethical standards, complied with the principles laid down in the Declaration of Helsinki.

\section{Preparation of glass ionomer materials}

Four different glass ionomers were tested: Fuji IX (GC Corp, Tokyo, Japan) and Ketac Molar (3M/ESPE, St. Paul, MN, USA) as conventional GICs, and Fuji II LC (GC Corp, Tokyo, Japan) and Vitrebond (3M/ ESPE, St. Paul, MN, USA) as resin-modified GICs. The composition of selected materials as per their manufacturers is presented in Table 1. Ionomers were polymerised in aseptic conditions as recommended by the manufacturers, in $4 \mathrm{~mm}$ in diameter and $2 \mathrm{~mm}$ thick rounded plates. CGICs were polymerised chemically in the air, and RMGICs with the Elipar

Table 1 Glass-ionomers used in the present study (according to manufacturers'data sheets)

\begin{tabular}{|c|c|c|}
\hline Glass ionomer group & $\begin{array}{c}\text { Ionomer } \\
\text { tested }\end{array}$ & Components \\
\hline \multirow{2}{*}{$\begin{array}{l}\text { Resin-modified glass } \\
\text { ionomer cements }\end{array}$} & $\begin{array}{l}\text { Fuji II LC (GC, } \\
\text { Tokyo, Japan) }\end{array}$ & $\begin{array}{l}\text { Powder: fluoroaluminosilicate glass } \\
\text { Liquid: polyacrylic acid and copolymer of acrylic and maleic acid, } \\
\text { 2-hydroxyethyl-methacrylate (HEMA), initiator, water. }\end{array}$ \\
\hline & $\begin{array}{l}\text { Vitrebond ( } 3 \mathrm{M} \\
\text { ESPE, St. Paul, } \\
\text { MN, USA) }\end{array}$ & $\begin{array}{l}\text { Powder: } \mathrm{SiO}_{2}, \mathrm{AlF}_{3}, \mathrm{ZnO}, \mathrm{Na}_{3} \mathrm{AlF}_{6}, \mathrm{SP}-940 \mathrm{~S} \text { glass powder, } \\
\text { disodiumhydrogenphosphate, diphenyliodoniumchloride } \\
\text { Liquid: conacid-isocyanatoethyl-methacrylateacrylic acid, HEMA, } \\
\text { bornandion, di-tert-butyl-p-cresol }\end{array}$ \\
\hline \multirow{2}{*}{$\begin{array}{l}\text { Conventional glass } \\
\text { ionomer cements }\end{array}$} & $\begin{array}{l}\text { Fuji IX } \\
\text { (GC, Tokyo, } \\
\text { Japan) }\end{array}$ & $\begin{array}{l}\text { Powder: fluoroaluminosilicate glass, polyacrylic acid powder } \\
\text { Liquid: polyacrylic acid, polybasic carboxylic acid }\end{array}$ \\
\hline & $\begin{array}{l}\text { Ketac Molar } \\
(3 \mathrm{M} \text { ESPE, } \\
\text { St. Paul, MN, } \\
\text { USA) }\end{array}$ & $\begin{array}{l}\text { Powder: fluoroaluminosilicate glass, } \mathrm{ZnO} \text {, polycarboxylic acid, } \\
\text { pigments } \\
\text { Liquid: water, copolymer acrylic calcium, maleic acid, tartaric acid, } \\
\text { benzoic acid }\end{array}$ \\
\hline
\end{tabular}


TriLight halogen curing unit $\left(650 \mathrm{~mW} \mathrm{~cm}^{-2}\right)$ from a distance of $2 \mathrm{~mm}$ for $40 \mathrm{~s}$. Polymerised ionomers were eluted for $1 \mathrm{~h}, 1$ day, and 5 days in extracellular saline (ECS), consisting of $40 \mathrm{mmol} \mathrm{L}^{-1} \mathrm{NaCl}, 3 \mathrm{mmol} \mathrm{L}^{-1}$ $\mathrm{KCl}, 1 \mathrm{mmol} \mathrm{L}^{-1} \mathrm{CaCl}_{2}, 1 \mathrm{mmol} \mathrm{L} \mathrm{MgCl}_{2}, 10 \mathrm{mmol} \mathrm{L}^{-1}$ HEPES, adjusted to $\mathrm{pH} 7.3-7.4$ with $\mathrm{NaOH}$. Material surface $v s$. ECS volume ratio was $1 \mathrm{~cm}^{2} \mathrm{~mL}^{-1}$ (17). The elutions of unpolymerised glass ionomers in ECS were set up in the same manner.

\section{Initiation of cell cultures and micronucleus assay}

To initiate the cell cultures, $0.5 \mathrm{~mL}$ of blood was introduced into a cell culture flask (Nunc $\mathrm{GmbH}$, Wiesbaden, Germany) containing $5 \mathrm{~mL}$ of RPMI medium (Gibco, Carlsbad, USA) supplemented with $15 \%$ foetal bovine serum (Sigma, St. Louis, USA), $10 \mu \mathrm{g} \mathrm{mL}^{-1}$ of phytohemagglutinin (Murex, Dartford, UK), $2.5 \mathrm{~g} \mathrm{~L}^{-1}$ of phenol red $\mathrm{pH}$ indicator (Sigma, St. Louis, USA), 100 IU of penicillin (Sigma, St. Louis, USA), and 100 IU of streptomycin (Sigma, St. Louis, USA). Duplicate cell cultures per donor were treated with the following four dilutions of each glass ionomer eluate: $10^{-1}, 10^{-2}, 10^{-3}$, and $10^{-4}$. Dilutions were prepared in RPMI medium, and $\mathrm{pH}$ values were adjusted at 7.2. The same treatment scheme was used for each of the three elution times ( $1 \mathrm{~h}, 1$ day, and 5 days). GIC eluates were initiated 5 days, 1 day, and $1 \mathrm{~h}$ prior to blood sampling. The whole blood cultures were treated for $72 \mathrm{~h}$. Simultaneously, negative control cultures were treated with the same volume of physiological solution of ECS, whereas the positive controls were treated with bleomycin (Sigma, St. Louis, USA) at the final concentration of $30 \mu \mathrm{g} \mathrm{mL}^{-1}$ for the 5 last hours of cultivation. Cytochalasin B (Sigma, St. Louis, Germany) was added at a final concentration of $6 \mu \mathrm{g} \mathrm{ml}^{-1}$ to the cultures after $44 \mathrm{~h}$ of incubation. Cultures were incubated at $37^{\circ} \mathrm{C}$ for $72 \mathrm{~h}$. After incubation, the same culture was simultaneously subjected to analysis by all techniques.

For micronucleus assay, cells were centrifuged, pretreated with physiological solution, and fixed with $3: 1(\mathrm{v} / \mathrm{v})$ methanol/acetic acid solution. They were then air-dried and stained with $5 \%$ Giemsa (Sigma, St. Louis, USA) (18). For each elution time and dilution tested, 1000 binucleated lymphocytes per duplicate slide per donor were analysed scoring the number of micronuclei. We applied the scoring criteria described by Fenech et al. (19).

\section{Cytotoxicity testing}

Using the trypan blue exclusion technique, the relative cell viability was tested $72 \mathrm{~h}$ after the cultures were initiated. For all tested ionomers, cytotoxicity of dilution $10^{-1}$ of 1-day eluates appeared to be higher than $17 \%$. Therefore, only the cultures treated with dilutions of $10^{-2}, 10^{-3}$, and $10^{-4}$ were analysed using micronucleus, alkaline, and hOGG1 modified comet assays for all elution periods. After the treatment of cell cultures with ionomer eluates $\mathrm{pH}$ indicator contained within the medium did not show any changes in $\mathrm{pH}$ value. After the end of cultivation period, $\mathrm{pH}$ of each cell culture was additionally checked by a SevenEasy $\mathrm{pH}$ meter (Metler-Toledo $\mathrm{GmbH}$, Schwertzenbach, Switzerland) and it was continuously $7.27 \pm 0.04$, which is, according to the manufacturer, the regular $\mathrm{pH}$ value for RPMI cell culture medium.

\section{Alkaline and hOGG1 modified comet assay}

Following the treatment, cultures were centrifuged, supernatant removed, and both alkaline and hOGG1 comet assays were performed on whole blood samples in accordance with the protocols by Singh et al. (20) and Smith et al. (21), respectively. All the chemicals were obtained from Sigma Chemical Company (Sigma-Aldrich, Munich, Germany).

Normal melting point agarose (NMP) $0.6 \%$ was layered on slides precoated with $1 \%$ NMP. Blood samples $(8 \mu \mathrm{L})$ were mixed with $0.5 \%$ low melting point agarose, placed on the slides, and immersed in standard ice-cold lysis solution ( $\mathrm{pH} 10)$ and stored overnight at $4{ }^{\circ} \mathrm{C}$. For the alkaline comet assay the standard procedure was followed (20). For the hOGG1 modified comet assay, following the lysis slides were rinsed in three changes of neutralisation buffer (40 mmol L-1 HEPES, $0.1 \mathrm{~mol} \mathrm{~L}^{-1} \mathrm{KCl}, 0.5 \mathrm{mmol} \mathrm{L}^{-1}$ EDTA, pH 7.4) for $5 \mathrm{~min}$ at room temperature. One parallel slide was treated with hOGG1 enzyme in neutralisation buffer $(\mathrm{V}=60 \mu \mathrm{L}$; final dilution 1:1000). The other parallel slide was treated with $60 \mu \mathrm{L}$ of neutralisation buffer only. Treatment was performed in a humidified chamber for $10 \mathrm{~min}$ at $37^{\circ} \mathrm{C}$ and followed by $15 \mathrm{~min}$ of denaturation $\left(1.5 \mathrm{~mol} \mathrm{~L}^{-1} \mathrm{NaCl}\right.$, 1 mmol L-1 $\mathrm{Na}_{2}$ EDTA, $\mathrm{pH} \mathrm{12.1)}$ and $20 \mathrm{~min}$ of electrophoresis at $0.7 \mathrm{~V} \mathrm{~cm}^{-1}, 300 \mathrm{~mA}$. The slides were neutralised in three changes of buffer $\left(0.4 \mathrm{~mol} \mathrm{~L}^{-1}\right.$ Tris-HCl, $\mathrm{pH}$ 7.5), 5 min each, stained with ethidium bromide $\left(20 \mathrm{~g} \mathrm{~mL}^{-1}\right)$ and examined using a $250 \mathrm{x}$ magnification fluorescence microscope (Olympus, 
Japan). A total of 100 comets per concentration tested were scored on each duplicate slide. The edges of the gel, occasional dead cells, and superimposed comets were avoided. Tail length and tail intensity were measured using Comet Assay IV analysis system (Perceptive Instruments Ltd., Suffolk, UK). Oxidative DNA damage was calculated as per the following description. For each donor, mean tail intensity was calculated separately for the slides treated with hOGG1 enzyme and for the slides treated with buffer. Further difference between those two values was obtained for each donor, indicating oxidative DNA damage. Results of hOGG1 comet assay were presented as mean tail lengths only, since in this type of assay modification percentage of DNA in tail is the most informative parameter (21).

\section{Statistical analysis}

Differences in the number of micronuclei treated and control lymphocytes were evaluated using chisquare and Fisher's LSD test. Regarding the comet assay endpoints, to normalise the distribution and to equalise the variances, a logarithmic transformation of data was applied. Differences between the groups were tested using ANOVA followed by Duncan's test. To evaluate oxidative DNA damage, differences between the means for the slides treated with enzyme and the corresponding slides treated with buffer only were tested using ANOVA followed by Duncan's post-hoc analysis. The level of significance was set at 0.05 .

\section{RESULTS}

Micronucleus assay did not show statistically increased micronucleus frequency for any of the eluates tested. A slightly increased number of micronuclei was detected in the cultures treated with $10^{-2}$ dilution of 1-h eluates of unpolymerised Vitrebond and Ketac Molar (Figure 1).

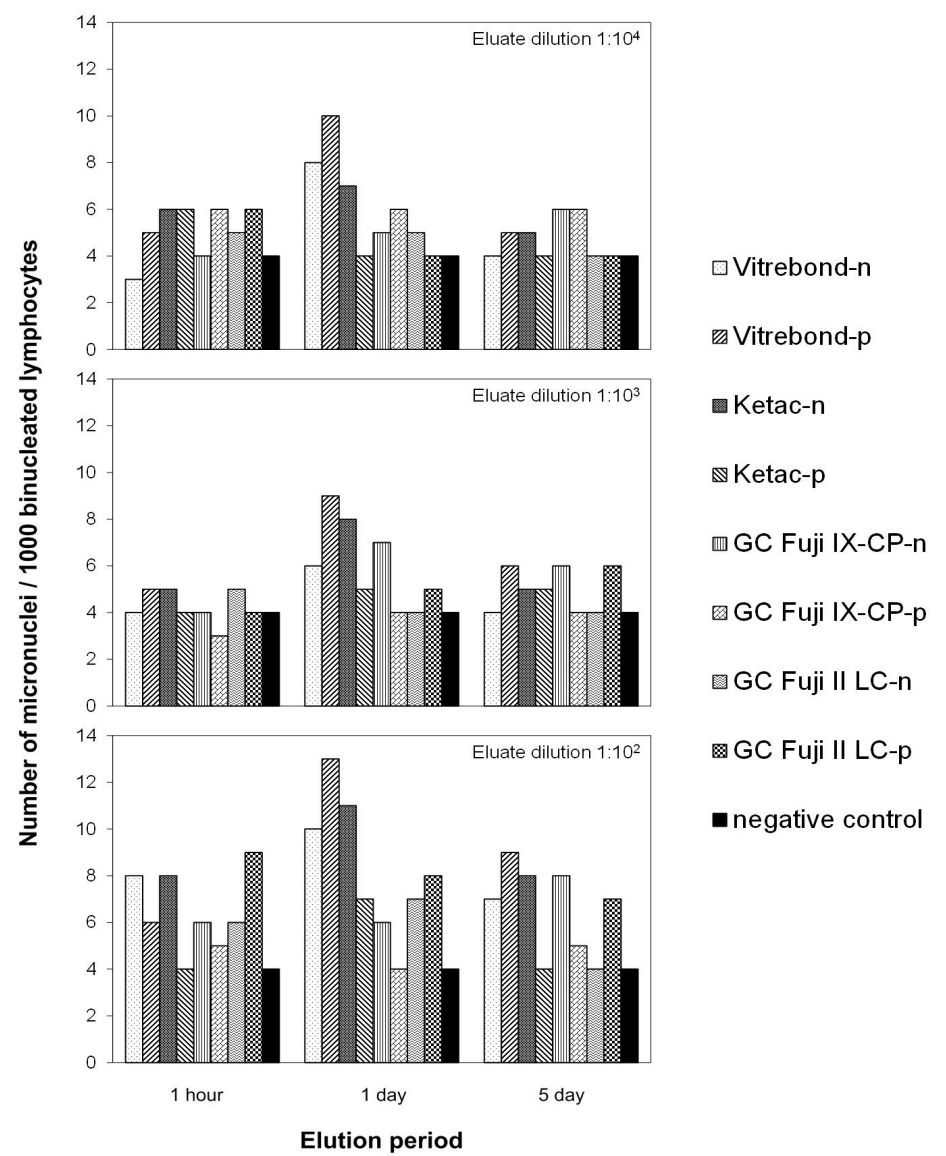

Figure 1 Number of micronuclei in lymphocyte cultures treated with different dilutions $\left(10^{-2}, 10^{-3}\right.$, and $\left.10^{-4}\right)$ of initial glass ionomer eluates $\left(1 \mathrm{~cm}^{2} \mathrm{~mL}^{-1}\right.$ of extracellular saline) after $1 \mathrm{~h}, 24 \mathrm{~h}$, and 5 days of elution. One thousand binucleated lymphocytes were analysed per treatment on each of three blood samples $p$ - polymerised, $n$ - unpolymerised 
Eluates of polymerised forms of these ionomers did not influence micronucleus frequency. Further, $10^{-2}$ and $10^{-3}$ dilutions of 1 -day eluates of unpolymerised Ketac Molar, and the polymerised form of GC Fuji II LC slightly, but insignificantly elevated the number of micronuclei (Figure 1).

Similarly, in the culture treated with dose eluates, a slightly increased micronucleus frequency compared to 1-h elution was found. Dilution $10^{-2}$ of 5-day eluates of polymerised Vitrebond and GC Fuji IX GP, and unpolymerised Ketac Molar induced further insignificant elevation of MN (Figure 1).

Neither did the comet assay show statistically increased tail length or Olive tail moment for any of the eluates of the tested glass ionomers, polymerised or unpolymerised. Again, slightly elevated DNA migration was detected in lymphocytes treated with $10^{-2}$ dilution of 1-h of both unpolymerised and polymerised Vitrebond, unpolymerised Ketac Molar, and polymerised Fuji II LC (Figures 2, 3). Later eluates did not show any differences regardless of their dilution or polymerisation state.

Application of hOGG1 modified comet assay did not indicate an increase in the 8-oxoguanine formation due to possible oxidative stress induced by resin monomers released form the tested glass ionomers (Table 2). A slight increase in tail intensity was observed for all tested materials $24 \mathrm{~h}$ after the initial setting, and only for the lowest eluate dilution $\left(10^{-2}\right)$. However, the increase was simultaneously observed for the slides treated with hOGG1 enzyme and the corresponding buffer treated slides. We did not observe any statistical difference in the percentage of DNA in tails due to hOGG1 treatment.

\section{DISCUSSION}

The study presents the results of genotoxicity evaluation of eluates of four glass ionomers: Fuji II LC and Vitrebond as resin-modified glass ionomer

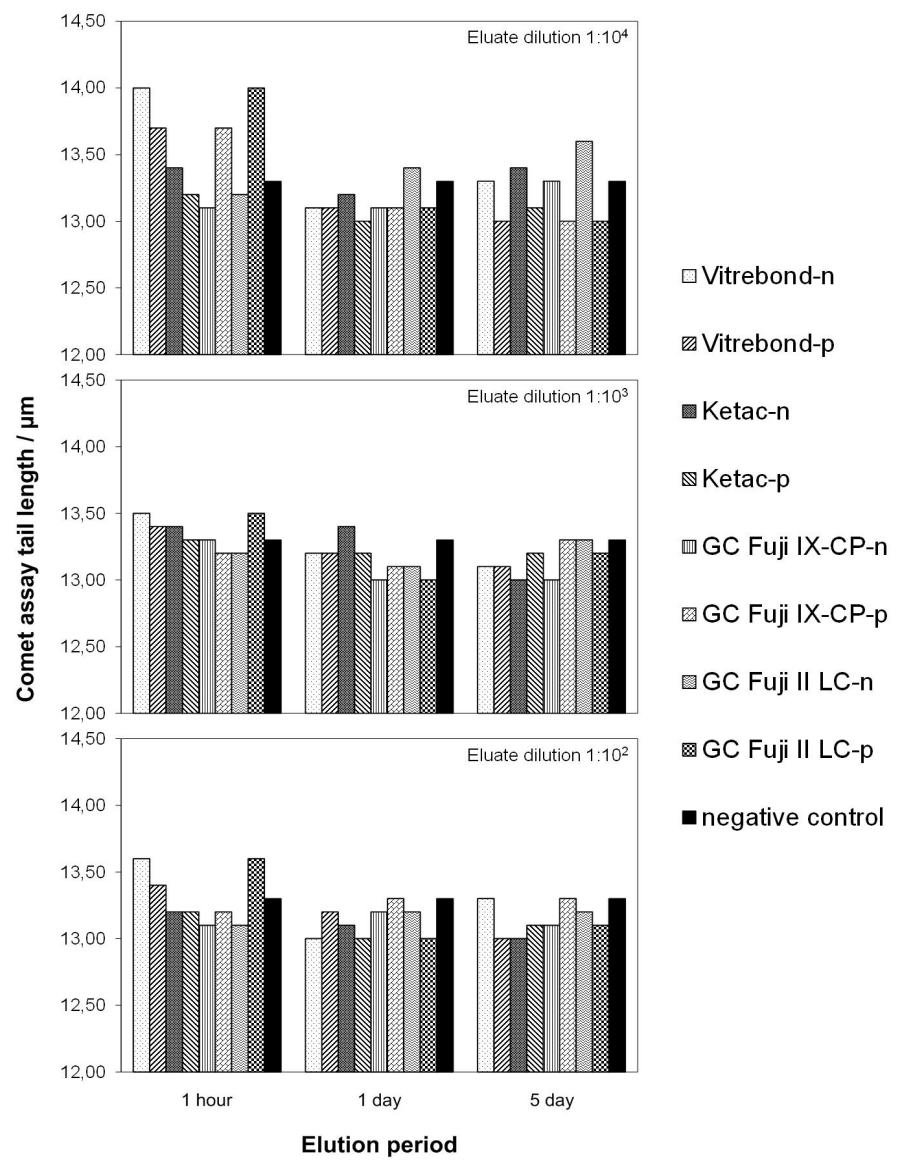

Figure 2 Tail length values for lymphocyte cultures treated with different dilutions $\left(10^{-2}, 10^{-3}\right.$, and $\left.10^{-4}\right)$ of initial glass ionomer eluates $\left(1 \mathrm{~cm}^{2} \mathrm{~mL}^{-1}\right.$ of extracellular saline $)$ after $1 \mathrm{~h}, 24 \mathrm{~h}$, and 5 days of elution. One hundred comets were analysed per treatment on each of three blood samples. $p$ - polymerised, $n$ - unpolymerised 


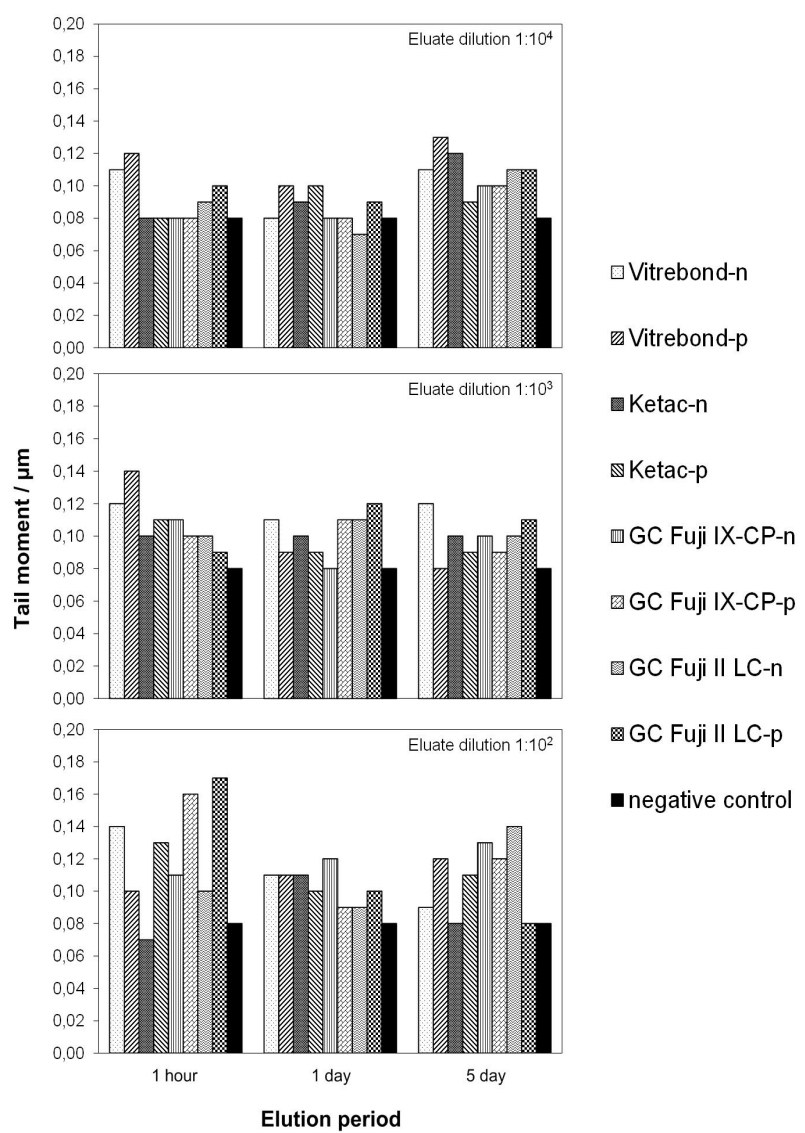

Figure 3 Mean tail moment values for lymphocyte cultures treated with different dilutions $\left(10^{-2}, 10^{-3}\right.$, and $\left.10^{-4}\right)$ of initial glass ionomer eluates ( $1 \mathrm{~cm}^{2} \mathrm{~mL}^{-1}$ of extracellular saline) after $1 \mathrm{~h}, 24 \mathrm{~h}$, and 5 days of elution. One hundred comets were analysed per treatment on each of three blood samples.

$p$ - polymerised, $n$ - unpolymerised

cements, and Fuji IX and Ketac Molar as conventional glass ionomer cements. We aimed to detect possible differences in the mechanisms of their genotoxicity that may arise due to differences in their composition and initiation of polymerisation (chemical or photoactivation). To get more information on their biocompatibility, glass ionomer cements were tested both in their unpolymerised and polymerised form. In this assessment two cytogenetic techniques were used: alkaline comet and micronucleus assay. Comet assay detects primary DNA damage that could result from direct interaction of monomers, initiators or any other leached components with genomic DNA. That type of damage does not require cell division to be expressed and evaluated (22). Modification of the comet assay procedure by exposing the isolated DNA to hOGG1 enzyme allows to specifically detect 8-oxoguanine base that arises as a result of oxidative DNA damage. Micronucleus assay detects DNA lesions that are not repaired properly and after replication result in the formation of acentric chromosome fragments. It also detects damage of the cell spindle disabling chromosomes to be attached properly and chromatids to be divided between the newly forming cells. Thus, contrary to the comet assay, micronucleus assay enables detection of both types of genotoxic agents, clastogens and aneugens (18).

It has been proven that due to incomplete polymerisation, residual monomers (HEMA, BisGMA) are leached from dental materials (23). In our study we did not detect any genome damage in the above mentioned period of time and eluate dilutions using comet assay. However, micronucleus assay indicated a slight but insignificant increase in the micronucleus frequency in lymphocytes treated with the lowest dilution $\left(10^{-2}\right)$ of 1-day eluate of polymerised GC Fuji II LC, and 5-day eluates of polymerised Vitrebond and GC Fuji IX GP. Unpolymerised Vitrebond and Ketac Molar insignificantly elevated micronuclei incidence as early as after 1-h elution indicating faster leaching of active components from unpolymerised materials. Unpolymerised Ketac Molar slightly influenced micronuclei induction throughout the entire period of 5-day elution indicating persistence of its leached active components, presumably $\mathrm{ZnO}$ that was suspected to be clastogenic and that was not 
Table 2 Results of hOGG1 modified comet assay presenting mean tail intensity values (\% DNA in comet's tail). The results obtained for the slides treated with buffer and the corresponding slides treated with enzyme are shown for each treatment. One hundred comets were analysed per treatment on each of three blood samples

\begin{tabular}{|c|c|c|c|c|c|}
\hline \multirow{2}{*}{ Glass ionomer } & \multirow{2}{*}{ Form } & \multirow{2}{*}{$\begin{array}{l}\text { Eluate } \\
\text { dilution }\end{array}$} & \multicolumn{3}{|c|}{$\begin{array}{c}\text { Oxidative DNA damage after elution of glass } \\
\text { ionomers (mean } \pm \text { SD) }\end{array}$} \\
\hline & & & $1 \mathrm{~h}$ & 1 day & 5 days \\
\hline \multirow{6}{*}{ Vitrebond } & \multirow{3}{*}{ Unpolymerised } & $10^{-2}$ & $0.70 \pm 0.32$ & $1.98 \pm 0.94$ & $0.12 \pm 0.06$ \\
\hline & & $10^{-3}$ & $0.16 \pm 0.08$ & $1.86 \pm 0.98$ & $0.08 \pm 0.02$ \\
\hline & & $10^{-4}$ & $0.14 \pm 0.06$ & $1.02 \pm 0.86$ & $0.06 \pm 0.00$ \\
\hline & \multirow{3}{*}{ Polymerised } & $10^{-2}$ & $0.18 \pm 0.08$ & $1.18 \pm 0.80$ & $0.05 \pm 0.03$ \\
\hline & & $10^{-3}$ & $0.12 \pm 0.04$ & $1.33 \pm 0.82$ & $0.06 \pm 0.01$ \\
\hline & & $10^{-4}$ & $0.24 \pm 0.07$ & $0.92 \pm 0.47$ & $0.04 \pm 0.01$ \\
\hline \multirow{6}{*}{ Ketac Molar } & \multirow{3}{*}{ Unpolymerised } & $10^{-2}$ & $0.16 \pm 0.03$ & $1.53 \pm 0.68$ & $0.34 \pm 0.11$ \\
\hline & & $10^{-3}$ & $0.02 \pm 0.00$ & $0.95 \pm 0.23$ & $0.13 \pm 0.05$ \\
\hline & & $10^{-4}$ & $0.03 \pm 0.01$ & $1.31 \pm 0.54$ & $0.11 \pm 0.01$ \\
\hline & \multirow{3}{*}{ Polymerised } & $10^{-2}$ & $0.27 \pm 0.09$ & $1.40 \pm 0.86$ & $0.16 \pm 0.03$ \\
\hline & & $10^{-3}$ & $0.04 \pm 0.00$ & $0.90 \pm 0.32$ & $0.22 \pm 0.08$ \\
\hline & & $10^{-4}$ & $0.14 \pm 0.05$ & $0.13 \pm 0.06$ & $0.18 \pm 0.06$ \\
\hline \multirow{6}{*}{ GC Fuji IX GP } & \multirow{3}{*}{ Unpolymerised } & $10^{-2}$ & $0.01 \pm 0.00$ & $1.52 \pm 0.27$ & $0.18 \pm 0.03$ \\
\hline & & $10^{-3}$ & $0.14 \pm 0.02$ & $1.07 \pm 0.09$ & $0.24 \pm 0.09$ \\
\hline & & $10^{-4}$ & $0.07 \pm 0.05$ & $0.86 \pm 0.14$ & $0.06 \pm 0.02$ \\
\hline & \multirow{3}{*}{ Polymerised } & $10^{-2}$ & $0.14 \pm 0.04$ & $0.97 \pm 0.07$ & $0.11 \pm 0.03$ \\
\hline & & $10^{-3}$ & $0.15 \pm 0.04$ & $1.13 \pm 0.74$ & $0.14 \pm 0.02$ \\
\hline & & $10^{-4}$ & $0.01 \pm 0.01$ & $0.98 \pm 0.55$ & $0.12 \pm 0.02$ \\
\hline \multirow{6}{*}{ GC Fuji II LC } & \multirow{3}{*}{ Unpolymerised } & $10^{-2}$ & $0.13 \pm 0.05$ & $0.93 \pm 0.28$ & $0.01 \pm 0.02$ \\
\hline & & $10^{-3}$ & $0.09 \pm 0.03$ & $1.20 \pm 0.23$ & $0.14 \pm 0.03$ \\
\hline & & $10^{-4}$ & $0.08 \pm 0.03$ & $0.87 \pm 0.17$ & $0.12 \pm 0.03$ \\
\hline & \multirow{3}{*}{ Polymerised } & $10^{-2}$ & $0.11 \pm 0.03$ & $1.04 \pm 0.19$ & $0.14 \pm 0.03$ \\
\hline & & $10^{-3}$ & $0.02 \pm 0.01$ & $1.17 \pm 0.41$ & $0.10 \pm 0.02$ \\
\hline & & $10^{-4}$ & $0.04 \pm 0.03$ & $0.92 \pm 0.47$ & $0.11 \pm 0.02$ \\
\hline \multicolumn{3}{|c|}{ Negative control ( $22 \mu \mathrm{L}$ extracellular saline) } & $0.02 \pm 0.02$ & $0.81 \pm 0.18$ & $0.03 \pm 0.01$ \\
\hline \multicolumn{3}{|c|}{ Positive control $\left(0.1 \mathrm{mmol} \mathrm{L}^{-1} \mathrm{H}_{2} \mathrm{O}_{2} 10 \mathrm{~min}\right)$} & $16.4 \pm 1.82^{1}$ & $28.07 \pm 1.20^{1}$ & $15.7 \pm 1.05^{1}$ \\
\hline
\end{tabular}

${ }^{1}$ statistically significant oxidative DNA damage, $p<0.05$ between the corresponding slides treated with hOGG1 enzyme and buffer only. Oxidative DNA damage was calculated as difference in tail intensity values between hOGG1 and buffer treated slides.

contained in other glass-ionomers (24). However, the observed effects could not at all be considered biologically relevant. Considering the effect of Vitrebond and Fuji II LC on micronucleus frequency, it would be mainly mediated by HEMA that is known to be genotoxic (25). Contrary to Kleinsasser et al. (25) that reported increased DNA migration ability of human lymphocytes exposed to HEMA, we did not detect any effect of ionomers containing this monomer on comet assay endpoints. Thus, the observed fluctuations in the number of micronuclei, although biologically insignificant, might have been mediated by slight anuegenic effect of monomers. Vitrebond's genotoxicity could be additionally mediated by dipheniliodiumchloride (DPICI) that is used as the initiator. Leyhausen et al. (26) reported that DPICI that was leached from polymerised Vitrebond exhibited genotoxic activity. These results may suggest that even from the unpolymerised form of ionomers, after mixing powder and liquid components HEMA could not be leached in the amounts needed to induce significant DNA damage under the experimental conditions used in our evaluation. The choice of solvent vehicle used in elution might also be critical. Kleinsasser et al. (25) used organic solvent DMSO, and we used extracellular saline as the main polar solvent saline solution. Ribeiro et al. (27) published the results on genotoxic evaluations of Vitrebond and Ketac Molar on Chinese hamster ovary (CHO) and mouse lymphoma (L5178Y) cell lines 
using comet assay. Unlike in our study, they tested the components separately without mixing them. The results showed that powders from assay did not show genotoxic effects. The authors observed increased DNA migration only for the highest concentration of Ketac Molar powder phase $\left(100 \mu \mathrm{g} \mathrm{mL}^{-1}\right.$ and $\left.1000 \mu \mathrm{g} \mathrm{mL}^{-1}\right)$, and the highest concentration of Vitrebond liquid phase $(1 \%)$. No measurable genotoxicity was found in the liquid from Ketac Molar in all dilutions tested (0.01-1\%). In the study of Bakopoulou et al. (28), 72 h-eluates of Ketac Cem significantly increased the frequency of sister chromatid exchanges and chromosomal aberrations in human lymphocyte cultures.

Stea et al. (29) evaluated genotoxicity of Vitrebond eluates in human lymphocytes cultures using sister chromatid exchange (SCE) assay. The authors reported increased SCE frequency for $10^{-2}$ eluate dilution of unpolymerised Vitrebond and $10^{-1}$ of the polymerised one. Bakopoulou et al. (28) showed Vitrebond's eluate to be very cytotoxic, as the first series of dilutions of both materials caused a complete mitotic arrest in lymphocyte cultures but the authors used ten-fold lower dilutions of eluate in culture treatment than we did in the present study. Also, the eluate derived from Vitrebond specimens $(5 \mathrm{~mm}$ in diameter and $2 \mathrm{~mm}$ thick) caused extensive genotoxicity after $24 \mathrm{~h}$, increasing the frequencies of sister chromatid exchange and the number of chromosomal aberrations (28). Of all the observed insignificant effects on micronucleus frequency, the one caused by Fuji IX was the lowest.

The main deficiency of ex vivo tests is their questionable clinical relevance. Although the effects detected in in vitro studies could not be directly extrapolated into in vivo conditions, they are informative and could indicate a potential degree of health risk that may arise from using certain chemical compounds in dental restoration. In vitro studies provide limited responses due to the lack of biological and physiological components that cannot be replicated in the laboratory. The largest limitations of this study were low concentrations used to reproduce the situation in the mouth and the type of cell on which we carried out the research. It would have been a better solution to have used oral cells that are the first line of defence in the oral cavity in direct contact with the tested material. We could suggest that under the conditions presented in this study, in non-toxic concentrations range, the evaluated glass ionomer cements (Vitrebond, Ketac Molar, Fuji IX GP, and
Fuji II LC) did not exhibit any biologically relevant genotoxic activity on peripheral blood lymphocytes in vitro measured by comet and micronucleus assays, nor were they able to induce oxidative DNA damage. With respect to such results, a slight and insignificant increase in the micronucleus number might raise suspicion of their restricted aneugenicity. Altogether, under the experimental conditions used in the study, the tested glass ionomers showed a satisfying level of biocompatibility.

\section{Acknowledgements}

This investigation was supported by the Croatian Ministry of Science, Education, and Sports as part of the Themes No: 022-0222148-2137 and No: 0650650444-0418.

\section{Conflict of interest}

The authors declare no conflict of interest.

\section{REFERENCES}

1. Schmalz G, Arenholt-Bindslev D. Biocompatibility of dental materials: Springer Verlang Berlin Heidelberg; 2009.

2. Bogović A, Nižetić J, Galić N, Želježić D, Micek V, Mladinić M. The effects of hyaluronic acid, calcium hydroxide, and dentin adhesive on rat odontoblasts and fibroblasts. Arh Hig Rada Toksikol 2011;62:155-61. PMID:21705303.

3. Tadin A, Galic N, Zeljezic D, Mikelic Vitasovic B, Marovic D, Kovacic I. Ex vivo evaluation of genotoxic effects of four dental adhesives on human leukocytes. J Dent Sci 2013;8:3743. doi:10.1016/j.jds.2012.12.001.

4. Tadin A, Galic N, Mladinic M, Marovic D, Kovacic I, Zeljezic D. Genotoxicity in gingival cells of patients undergoing tooth restoration with two different dental composite materials. Clin Oral Investig 2014;18:87-96. PMID: 23385426.

5. Tyas MJ. Clinical evaluation of glass-ionomer cement restorations. J Appl Oral Sci 2006;14(Suppl):10-3. PMID:19089080.

6. Berzins DW, Abey S, Costache MC, Wilkie CA, Roberts HW. Resin-modified glass-ionomer setting reaction competition. J Dent Res 2010;89:82-6. PMID:19966038.

7. Coutinho E, Yoshida Y, Inoue S, Fukuda R, Snauwaert J, Nakayama Y, De Munck J, Lambrechts P, Suzuki K, Van Meerbeek B. Gel phase formation at resin-modified glassionomer/tooth interfaces. J Dent Res 2007;86(7):656-61. PMID:17586714.

8. Aranha AM, Giro EM, Souza PP, Hebling J, de Souza Costa CA. Effect of curing regime on the cytotoxicity of resinmodified glass-ionomer lining cements applied to an odontoblast-cell line. Dent Mater 2006;22:864-9. PMID:16388848. 
9. Xie D, Brantley WA, Culbertson BM, Wang G. Mechanical properties and microstructures of glass-ionomer cements. Dent Mater 2000;16:129-38. PMID:11203534

10. de Souza Costa CA, Hebling J, Garcia-Godoy F, Hanks CT. 2003. In vitro cytotoxicity of five glass-ionomer cements. Biomaterials 2003;24:3853-8. PMID:12818558.

11. Souza PP, Aranha AM, Hebling J, Giro EM, Costa CA. In vitro cytotoxicity and in vivo biocompatibility of contemporary resin-modified glass-ionomer cements. Dent Mater 2006;22:838-44. PMID:16387357.

12. Stanislawski L, Daniau X, Lauti A, Goldberg M. Factors responsible for pulp cell cytotoxicity induced by resinmodified glass ionomer cements. J Biomed Mater Res 1999;48:277-88. PMID:10398031.

13. Geurtsen W. Biocompatibility of resin-modified filling materials. Crit Rev Oral Biol Med 2000;11:333-55. PMID:11021634.

14. Koulaouzidou EA, Papazisis KT, Economides NA, Beltes P, Kortsaris AH. Antiproliferative effect of mineral trioxide aggregate, zinc oxide-eugenol cement, and glass-ionomer cement against three fibroblastic cell lines. J Endod 2005;31:44-6. PMID:15614005.

15. do Nascimento AB, Fontana UF, Teixeira HM, Costa CA. Biocompatibility of a resin-modified glass-ionomer cement applied as pulp capping in human teeth. Am J Dent 2000;13:28-34. PMID:11763899.

16. Six N, Lasfargues JJ, Goldberg M. In vivo study of the pulp reaction to Fuji IX, a glass ionomer cement. J Dent 2000;28:413-22. PMID:10856806.

17. ISO standard 10993/12. Biological evaluation of medical devices-Part 12: sample preparation and reference material. ed. G ISO: Geneva;1996. [Displayed 23 February 2013] Available at https://law.resource.org/pub/ie/ibr/is.en. iso.10993.12.2012.html.

18. Fenech M. The cytokinesis-block micronucleus technique and its application to genotoxicity studies in human populations. Environ Health Perspect 1993;101(Suppl) 3:101-7. PMID: 8143599.

19. Fenech M, Chang WP, Kirsch-Volders M, Holland N, Bonassi S, Zeiger E; HUman MicronNucleus project. HUMN project: detailed description of the scoring criteria for the cytokinesisblock micronucleus assay using isolated human lymphocyte cultures. Mutat Res. 2003 Jan 10;534(1-2):65-75. PMID 12504755 .
20. Singh NP, McCoy MT, Tice RR, Schneider EL. A simple technique for quantitation of low levels of DNA damage in individual cells. Exp Cell Res 1988;175:184-91. PMID:3345800.

21. Smith CC, O'Donovan MR, Martin EA. hOGG1 recognizes oxidative damage using the comet assay with greater specificity than FPG or ENDOIII. Mutagenesis 2006;21:18590. PMID: 16597659

22. Collins AR. The comet assay for DNA damage and repair: principles, applications, and limitations. Molr biotechnol 2004;26:249-61. PMID:15004294

23. Kawahara T, Nomura Y, Tanaka N, Teshima W, Okazaki M, Shintani H. Leachability of plasticizer and residual monomer from commercial temporary restorative resins. J Dent 2004:32:277-83. PMID:15053910.

24. Dufour EK, Kumaravel T, Nohynek GJ, Kirkland D, Toutain H. Clastogenicity, photo-clastogenicity or pseudo-photoclastogenicity: Genotoxic effects of zinc oxide in the dark, in pre-irradiated or simultaneously irradiated Chinese hamster ovary cells. Mutat Res 2006;607:215-24. PMID: 16797222.

25. Kleinsasser NH, Wallner BC, Harréus UA, Kleinjung T, Folwaczny M, Hickel R, Kehe K, Reichl FX. Genotoxicity and cytotoxicity of dental materials in human lymphocytes as assessed by the single cell microgel electrophoresis (comet) assay. J Dent 2004;32:229-34. PMID:15001288.

26. Leyhausen G, Abtahi M, Karbakhsch M, Sapotnick A, Geurtsen W. Biocompatibility of various light-curing and one conventional glass-ionomer cement. Biomaterials 1998;19:559-64. PMID: 9645563.

27. Ribeiro DA, Marques ME, Salvadori DM. Genotoxicity and cytotoxicity of glass ionomer cements on Chinese hamster ovary (CHO) cells. J Mater Sci Mater Med 2006;17:495-500. PMID: 16691346.

28. Bakopoulou A, Mourelatos D, Tsiftsoglou AS, Giassin NP, Mioglou E, Garefis P. Genotoxic and cytotoxic effects of different types of dental cement on normal cultured human lymphocytes. Mutat Res 2009;672:103-12. PMID:19028600.

29. Stea S, Visentin M, Cervellati M, Verri E, Cenni E, Savarino L, Stea S, Pizzoferrato A. 1998. In vitro sister chromatid exchange induced by glass ionomer cements. J Biomed Mater Res 1998;40:545-50. PMID:9599030. 


\section{Sažetak}

Procjena in vitro toksičnosti stakleno-ionomernih cemenata primjenom mikronukleus testa, alkalnog komet testa i komet testa modificiranog hOGG1 enzimom

Svrha istraživanja bila je procijeniti genotoksični potencijal komponenata koje izlučuju dva konvencionalna samopolimerizirajuća stakleno-ionomerna cementa (Fuji IX i Ketac Molar) te svjetlosno polimerizirajući i smolom modificirani stakleno-ionomerni cementi (Vitrebond, Fuji II LC). Istraživanje je provedeno na ljudskim limfocitima primjenom alkalnog komet testa, komet testa modificiranog hOGG1 enzimom te mikronukleus testa. Svaki materijal, polimerizirani i nepolimerizirani, eluiran je u fiziološkoj otopini $\left(1 \mathrm{~cm}^{2} \mathrm{~mL}^{-1}\right)$ tijekom jednog sata, jednog dana i tijekom 5 dana. Kulture limfocita tretirane su eluatima $\mathrm{u}$ razrjeđenjima $10^{-2}, 10^{-3}$ i $10^{-4}$. Alkalnim komet testom nisu zabilježene promjene u migraciji DNA iz tretiranih stanica bez obzira na ispitani ionomer, vrstu polimerizacije i trajanje elucije. Izloženost staklenim ionomerima nije značajno utjecala na učestalost mikronukleusa. Primjenom hOGG1 modificiranog komet testa nije zamijećeno oksidativno oštećenje DNA u tretiranim limfocitima. Dobiveni rezultati upućuju na visoki stupanj biokompatibilnosti svih testiranih materijala koji su se koristili u eksperimentalnim uvjetima.

KLJUČNE RIJEČI: biokompatibilnost; citotoksičnost; genotoksičnost; limfociti; oštećenje DNA

\section{CORRESPONDING AUTHOR:}

Antonija Tadin

Department of Endodontics and Restorative Dental Medicine Study of Dental Medicine, School of Medicine, University of Split Soltanska 2, 21000 Split, Croatia

E-mail:atadin@mefst.hr 